\title{
9 Pedagogical Segregation from Students' Perspectives
}

\section{Catarina Schmidt}

The divide between low- and high-performing schools, as well as the school segregation this creates, now evidently characterises the Swedish educational landscape. Low-performing schools' merit points are clearly below the national average, and many students in these schools have difficulties reaching the minimal standards for entering upper secondary school, while high-performing schools make up for the totally opposite situation. This pedagogical segregation has been reinforced by factors of a high socio-economic index and by the free school choice (Brandén \& Bygren, 2018; NAE, 2012, 2020). Many students in low-performing schools live within urban or rural areas, characterised by a high socio-economic index and low possible school choices. Reports from NAE $(2018,2019 \mathrm{a})$ and the Governments' Office (SOU 2020, p. 46) show that since the end of the 20th century, students' socio-economic backgrounds have become increasingly significant for students' school success regarding complete marks and qualification for upper secondary school.

Also, we know that among the heterogeneous group of multilingual students, that is, $28 \%$ of the students with another first language than the majority language, general academic results are below those achieved by students with monolingual backgrounds (NAE, 2019b) - a situation that links strongly to socio-economic conditions. Unfavourable socio-economic conditions in urban and multicultural areas in Sweden have increased, inducing residential segregation (Aldén \& Hammarstedt, 2016; Bunar et al., 2021; Johansson \& Hammarén, 2011; SOU 2020, p. 46). Residential segregation has reinforced school segregation, which, in turn, has been reinforced by the segregating forces produced by free school choices, thereby making students become increasingly divided among schools, considerably based on their socio-economic backgrounds. At the actual school reported in this chapter, the circumstances of high socio-economic index, segregation and diverse language backgrounds are intertwined.

This chapter examines pedagogical segregation from students' perspectives within a school, here named Oak School, which, according to statistics from the National Agency of Education, is low-performing. Students' voices coming forward in this chapter are affected by socio-economic and residential segregation, since they live and school in an urban area characterised by such inequalities. Asking questions like 'what kinds of classroom pedagogies do these students experience within this specific low-performing school context and how do these students perceive these pedagogies?' is 


\section{Catarina Schmidt}

crucial to reflect on. This chapter will specifically focus on how the actual teaching that the students are involved in is organised and performed in Swedish subjects and the Natural Sciences, including the students' experiences and thoughts on this.

Previous studies, which this chapter adds to, highlight the risk of misery descriptions of underprivileged settings in which concepts like diversity or multiculturalism tends to equate with school areas with a larger proportion of migrated inhabitants with a weaker social position (Bunar, 2011; Wedin, 2015). For individual students, this includes the risk of developing a low self-image, a feeling of not belonging, or being discounted as a legitimate citizen (Cummins, 2001; Runfors, 2003). In order not to reinforce a deficit discourse, the importance of providing intellectually challenging education for second-language learners, combined with high support and explicit language teaching, has long been emphasised (Cummins \& Early, 2011; Gibbons, 2008). Also, previous research regarding second-language learners' opportunities for learning and developing knowledge highlights the importance of contextualisation, structure, high expectations and exploration-based activities, including opportunities for students' active participation and active language use (Cummins, 2001; Schleppegrell, 2004; Schmidt \& Skoog, 2017, 2018).

\section{Aims and Research Questions}

Drawing on the analysis of 16 video-recorded lessons and seven student focus group interviews, this chapter aims to examine the created classroom discourse, including the impact of teaching factors, and the student's perspectives on this. This aim will be addressed by elaborating on the following research questions:

1. What characterises the classroom pedagogies, that is, the organisation, the chosen content for teaching and learning, the possible interaction and communication, and what versions of knowledge emerge?

2. What students' perspectives regarding these classroom pedagogies emerge, and how can these perspectives be understood?

\section{Theoretical Standpoints}

Transmitting knowledge from one generation to another is simply the task of education. The role of knowledge within education is not an easily targeted concept. Educational knowledge includes generic subjects' content, that is, what is regarded as correct and just subject knowledge. Furthermore, according to the basic social values within the curriculum, educational knowledge should be combined with opportunities for students' influence and participation. The ways in which knowledge is drawn upon, situated and handled in classrooms enable students to access several knowledge versions with various opportunities for their learning and knowledge 
development. For example, a conception of knowledge as meaning-making might facilitate a multifaceted and dialogic approach with connections to other subjects, their own experiences and to the surrounding society, while an essentialistic view implies knowledge as unambiguous with frequent references to the actual subject (Wahlström, 2019). Another possible version of knowledge is knowledge as result-oriented, referring to when content and abilities are strongly linked to the content and knowledge requirements of the actual syllabus.

Powerful knowledge is, according to Young (2013), specialised regarding how it is produced and on what educational level, but it is also differentiated regarding the experiences that students bring to classrooms. In this way, powerful knowledge emerges as being, in Young's words, 'an epistemological issue that defines what constitutes the entitlement for students at different stages and in different specialist fields, and a social justice issue about the entitlement to knowledge of all students' (emphasis in original, p. 109). Since students' identities and backgrounds are multifaceted, they bring various experiences and prerequisites to classrooms. Within classrooms, students continuously define and redefine social situations, mirroring themselves regarding these through the classroom pedagogies they encounter. Students' identity making is 'part and parcel of the routines of everyday life, induced in the fine detail of everyday interaction' (Antaki \& Widdicombe, 1998, p. 1). The Swedish Education Act prescribes that education should be equal regardless of students' backgrounds (SFS 2010:800). A foundational educational and democratic question relates to how various classroom discourses, including the impact of differing knowledge versions, might have on teaching and learning in classrooms. Henceforth, this educational question will be illuminated regarding classroom pedagogies, which include the role of teaching factors, the curriculum content and the central actors of a classroom - the teachers and the students.

\section{Classroom Pedagogies}

Classroom pedagogies are, in this chapter, equivalent to the interplay between teaching factors, the curriculum and the classroom actors. Pedagogies in classrooms concern the ways in which the curriculum and the chosen content are translated and designed into teaching, and the role that the chosen teaching factors play in student's learning and knowledge development. Here, teaching factors refer to the organisation of classroom teaching and the possible interaction and communication within the classroom, occurring through the teacher's teaching talk and the student's learning talk (Alexander, 2008). These teaching factors are interdependent with curricula and vice versa (Doyle, 1992; Wahlström, 2018).

Teachers interpret the curriculum according to teaching content, aims and assessment criteria. Simultaneously, they make daily considerations regarding how to organise and conduct classroom teaching, including the choices of teaching talk regarding rote, recitation, instruction or dialogue, 


\section{Catarina Schmidt}

and discussion. Here, using rote is understood as the drilling of facts by repeating certain content or key concepts, while instructions inform the students on what to do and how to further (Wahlström, 2019). Drawing on Alexander's (2008) international discourse data, recitation was identified as the overall dominant category of teaching talk. The recitation category comprises closed-ended questions and brief recall answers, with a minimum of teacher feedback. Less frequently, and regarding deeper possibilities for meaningful feedback, were discussions and dialogues. Here, discussions are understood as exchanges of ideas and shared information between students, while dialogues achieve 'common understanding through structured cumulative questioning' to 'guide and prompt, reduce choices, minimise risk and error, and expedite the 'handover' of concepts and principles' (Alexander, 2008, p. 110). Teachers' teaching talks have, in turn, different meanings for the students' opportunities of learning talk, that is, their opportunities to listen to others, ask questions, act upon different kinds of answers, solve problems and the like (Alexander, 2008). The teaching factors of an organisation, teaching talk and learning talk are illustrated in Table 9.1.

Here, teaching factors are viewed as being situated within classroom practices. Students' opportunities for learning and achievement are viewed as being both a matter of knowledge development and the democratic purpose of education. Altogether, teaching factors mean the coordination of the three repertoires of organisation, teachers' teaching talk, and students' learning talk.

As we know, curricula are not only about aims, content and knowledge requirements regarding various subjects but are also shaped by basic social values, such as democratic aspects on influence and outspoken strives on equality. In translating any curriculum and its formation within a classroom, teachers and students are actors. Since students encounter classrooms from various positions, they are in different ways in a dependency state towards their teacher and the kinds of pedagogies they are offered. As actors in classroom pedagogies, teachers can, in various ways, create opportunities for their students to learn and develop knowledge and to become actors in their own learning. Classroom pedagogies, therefore, elucidate the pedagogical questions of what content to teach, why, and how. As Figure 9.1 illustrates, classroom pedagogies concern the ways in which the curriculum is translated and designed into teaching and the role that

Table 9.1 Teaching factors

\begin{tabular}{lll}
\hline Organisation & Teaching talk & Learning talk \\
\hline Whole-class teaching & Rote & Listening to others \\
Pair/group work & Recitation & Asking questions \\
Individual work & Instruction & Acting upon answers \\
& Monologue & Negotiating \\
& Dialogue/discussion & Reasoning \\
& & Solving problems
\end{tabular}




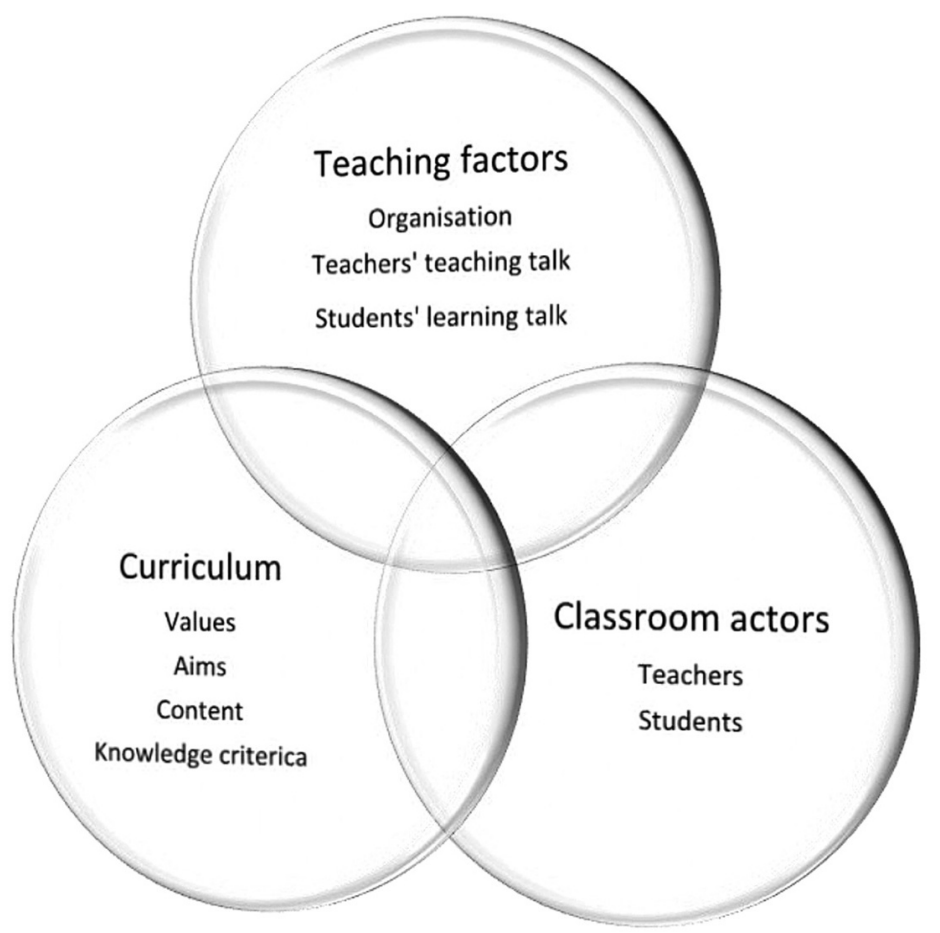

Figure 9.1 Classroom pedagogies

the teacher's chosen teaching factors play in the student's learning and knowledge development.

The transformation from the chosen curriculum's text content to the actual teaching content is understood by Doyle (1992) as constituting of curriculum events. Wahlström (2018) observed that the latter can be understood as if the teacher is authoring a basic text following the curriculum, determining what content to choose, how to introduce it and the perspectives to present it. The teacher's authored and communicated classroom text has, in turn, to be interpreted and acted upon by the students. It also means that the teacher, in one way or another and with higher or less awareness, decides on what knowledge version the students will access (Wahlström, 2018). Underlying knowledge assumptions, which affect lessons and the student's learning, can, as have been previously highlighted, focus on knowledge to meaning-making, as essentialistic or as result-oriented. When authoring a discursive text in the classroom, curriculum events are constituted where teaching factors are critical. Commonly, teachers design ongoing themes that persist over a sequence of lessons linked by their content, often when two or more subjects are integrated. Also, this speaks of an understanding of the curriculum as a coherent set of contexts and activities sequenced over days or weeks to build students' competencies towards desired goals. 


\section{Oak School - Contextualisation}

The setting of Oak School is diverse in terms of its residents' linguistic and cultural backgrounds. Drawing on 2019 statistics from NAE, 39\% of the students qualified for upper secondary school in Grade 9, compared with the national average of $73 \%$ for the same year. The study was conducted over one school year, 2018-2019, in Swedish subjects and the Natural Sciences, that is, in two classrooms, and in one Grade 8 class of 18 students.

Each student had access to an individual laptop but accessed this digital resource only at the beginning of Grade 8, despite the emphasis on the clarification of digital competence, such as confident and critical usage of digital technologies (Government Offices, 2017). Many students spoke a language other than Swedish in their homes, and one was a newly arrived student. While the school had no authorised teacher for Swedish as a Second Language ${ }^{1}$, most teachers were authorised in other subjects. Accordingly, the students in this school did not learn regarding the syllabus 'Swedish' as a second language, where differences regarding second-language learners are integrated, but instead from the Swedish syllabus directed towards learners having Swedish as their first language. For Oak School, the lack of authorised teachers in Swedish subjects as a second language, the delayed access to individual student laptops and a higher share of students affected by socio-economic inequalities are examples of underprivileged conditions.

\section{Methodology}

The case study of this specific school draws on ethnographic reflexive approaches, where I, as a researcher, observed and described actions regarding the articulated aim (Hammersley and Atkinson, 1989). Over one school year, 2018-2019, six lessons were video- and audio-recorded. One stationed-video camera was placed at the back of the classroom, and one extra microphone was placed at the front. The content and the structure of each specific lesson were the focus of these video recordings, together with the repertoires of teaching factors. Using video recordings enabled systematic documentation, capturing, and understanding of different ways in which the curriculum was organised and communicated in concrete classroom situations (Schmidt, 2019). Also, focus group interviews with the students were conducted, which enabled capturing a broader scale of thoughts and ideas (Xerri, 2018). A semi-structured interview guide was followed. Concurrently, my ambition was to listen carefully and follow the conversation and to ask follow-up questions or, if necessary, to return the conversation to the study's aim (Brinkmann, 2014). Seven interviews with 13 students were conducted during the school year (Table 9.2; the names are anonymised). 
Table 9.2 Focus group interviews, 15 students

\begin{tabular}{ll}
\hline $\begin{array}{l}\text { Interview one } \\
\text { October 2018 }\end{array}$ & Jenica, Benny, Admir, Mesude \\
$\begin{array}{l}\text { Interview two } \\
\text { October 2018 } \\
\text { Interview three } \\
\text { November 2018 }\end{array}$ & $\begin{array}{l}\text { Wahib, Abdul, Moukib } \\
\text { Anterview four }\end{array}$ \\
$\begin{array}{l}\text { Amale } \\
\text { November 2018 }\end{array}$ & Boris, Josef \\
$\begin{array}{l}\text { Interview five } \\
\text { March 2019 }\end{array}$ & Sara, Benny, Isra \\
Interview six & Boris, Josef \\
April 2019 & Jenica, Sara, Mesude \\
Interview seven & \\
April 2019 &
\end{tabular}

\section{Analysis of Classroom Discourse}

First, drawing on the designed curriculum tasks within the two subjects, teaching factors were analysed regarding organisation (regarding whole-class teaching, pair/group or individual work) and elements of the teachers' teaching talk (regarding rote, recitation, instruction, or monologue) (Wahlström, 2019). In this analysis, the discussion and dialogue categories were coded as one category. Also, lesson gaps (those gaps where the teacher waited for the class to be quiet and/or commented on students' behaviours) were added as a category in the analysis. Here, the category of lesson gaps is equal to disturbed classroom peace. Coming so far in the analysis, conclusions regarding the students' opportunities of learning talk, that is, their opportunities to listen to others, asking questions, acting upon different kinds of answers, solving problems, and so forth (Alexander, 2008), could be drawn. In this part of the analysis, a compilation regarding subject content and the selection of textual resources was also conducted.

Second, the analysis focused on the transcribed student interviews. Here, a content analysis (Hsieh \& Shannon, 2005) was conducted regarding the student's perspectives on the classroom pedagogies, that is, the organisation, the chosen content for teaching and learning, and their possibilities of interaction and communication. Here, the analysis aimed to investigate what classroom discourse emerged through the students' talk regarding various aspects of classroom pedagogies and also to investigate what kind of knowledge characterised the classroom discourse. The underlying assumptions for this were that discourses are created within social contexts, such as classroom practices, and that they form prevailing notions, or certain fixed ways of discussing and understanding what the words 'teaching and learning' (Foucault, 1993) are and should be about 
in this case. As these discourses influence and determine the borders for what is socially and culturally accepted, they identify what is seen as worth striving for.

\section{Results}

The presented results explore the classroom pedagogies regarding the chosen curriculum content, the teaching factors and the students as classroom actors. The curriculum content clarifies the chosen content, including the various resources presenting this content, while the teaching factors elucidate the used classroom repertoires of an organisation, the communication and the interaction. While presenting the classroom pedagogies in the following, the student's perspectives on this will be added together with my analytical reflections.

\section{Curriculum Content}

In Swedish subjects, the curriculum tasks of reading comprehension, debate articles, fact and fiction, poetry, and news articles frame classroom teaching, while the curriculum tasks in the Natural Sciences subject are electricity, heat, chemical elements, ecosystems and movement (Table 9.3).

The tasks listed in Table 9.3 and their contents were presented from various resources, such as textbooks, fictional texts, and digital resources. The textual resources in Swedish subjects included printed resources, such as textbooks, newspapers, and fiction literature, together with educational video clips and motion pictures. The chosen textual resources in the Natural Sciences comprised, during the first semester, a printed textbook combined with educational videos. In the second semester, the textbook was replaced by a digitised educational textual resource, covering all subjects in the Natural Sciences, including visual and written information and shorter videos, but still, other educational videos were used. Concrete materials for conducting scientific laboratory exercises were not drawn upon or used. In both classrooms, the students used their laptops and the digital resource Google Classrooms.

Table 9.3 Curriculum tasks

\begin{tabular}{ll}
\hline Swedish & Natural sciences \\
\hline Task one. Reading comprehension & Task six. Electricity \\
Task two. Debate articles & Task seven. Heat \\
Task three. Fact and fiction & Task eight. Chemical elements \\
Task four. Poetry & Task nine. Ecosystems \\
Task five. News articles & Task ten. Movement \\
\hline
\end{tabular}




\section{Students' Perspectives - Curriculum Content}

All the students agreed that the teacher decides on what content to teach about, and most of them mention the curriculum as a reason for the teacher's choice of content. The students, Jenica, Benny, Admir, and Mesude, stated collectively that the teacher in Swedish occasionally refers to the curriculum and that the teacher in the Natural Sciences does not.

Many students expressed the idea that the teacher in Swedish also chooses teaching content regarding the student's everyday lives. In task one, the students collectively read the youth novel Onsdag kväll, strax före sju [Wednesday Evening, Just Before Seven] (Berggren, 2016). In this novel and in the movie Màste gitt [Have to Walk Away] (Zubak, 2017), being part of task two, a suburban context with elements of violence is portrayed. Referring to the novel, Wahib observes, 'This book is precisely about us.' While some of the students, like Wahib, consider the novel as realistic, other students claim that the novel's description of a 'suburb' does not correspond with their experiences.

All the students were aware that they should develop certain abilities using various teaching content in Swedish subjects, and they gave several examples of this. Also, referring to the novel, Wahib states, 'Well, you read it, then you summarise it, and by that, you develop reading comprehension.' Referring to task two, Benny says, 'Everyone has different opinions, so you have to bring them forward.' Jenica adds, 'You have to be able to express your opinions.' Admir listens and takes slightly another direction than Benny and Jenica when observing, 'It is about correctness of the Swedish language, like reading with fluency and writing with correct grammar.' Following this last utterance, Josef says on another occasion, 'You cannot use suburban language or slang; you have to know how to start and end a sentence, that is important.' By this utterance, Josef highlights that, as students, they should develop their ability to use what he refers to as 'correct Swedish.'

Referring to the Natural Sciences and what they are to learn in these subjects, the students highlighted the importance of knowing about, for example, how electricity works. The students, Wahib, Abdul, and Moukib, mentioned Ohm's law, and Moukib continues, 'Through electricity, we as humans have accomplished great change.' The students, Perjsa, Moukib, Wahib, Diana, and Amale, described how they are to learn about the ecosystem in task nine, and started laughing suddenly. These students explained that they found the situation a bit absurd since they, according to themselves, are having difficulties with explaining what they are actually learning and why. Also, Boris and Josef found it hard to explain the content they are learning about, referring to the same task. Boris says, 'It is like bacteria and bugs in nature.'

Several students expressed dissatisfaction with the digitised educational resource Digilär, which considerably represents the content of the Natural Sciences during the second semester. Sara and Isra expressed that 'they do not 


\section{2}

understand anything.' The reason for this, according to these last students, is due to 'many difficult words and concepts.' These students described that they do not take notes any longer; rather, they take photos on the screen with their mobile phones. Also, Admir criticised the digital resource, saying, 'Give me a book, I go astray at the Internet.' Admir explains further:

They say to me, prepare yourself before the test. I go in on the Internet. Then, for example, if you forget the password, you have to provide many codes and stuffs. Well, then if you do not get the code, you cannot study. So, the test goes to the * with it. So, I say, give me a book, then I know what pages to study and so on.

Another student, Moukib, says, 'The teacher says one thing, and Digilär another thing, so we do not know who is right.' Benny, however, expresses that 'Digilär is kind of factual book in many subjects,' continuing, 'it works fine for me,' while Jenica nods in agreement. Sara accounts that the increased use of internet-based recourses also means that messages pop up steady. She explains, 'For example, we have a group on Facebook at school, where the teachers write information about tests and so on, or it could be a student adding a video.'

\section{Analytical Reflections - Curriculum Content}

The student's perspectives reveal that they do not think it is possible for them to have some influence on what content to learn from. Instead, the students expressed that the teachers should conduct the content selection on curriculum basis. Concurrently, some of the students express a mistrust regarding this professional selection in the subjects of the Natural Sciences. The content from which the students are going to learn in the Natural Sciences focuses, according to the student's expressed experiences, on subject-specific concepts. The content from which the students are going to learn in Swedish subject focuses, according to the student's expressed experiences, on fiction with two alternatives of retold suburban contexts with elements of violence, and other textual resources, aiming at developing communicative abilities. Several students expressed dissatisfaction and confusion regarding the digitised resource Digilär, and because of this and the classroom pedagogies, as will later be shown, several students do not seem to make sense of or reach an understanding of the curriculum content presented by this resource. The classroom discourse that emerges regarding the curriculum content is shaped by a narrowed content in the Natural Sciences (i.e. concepts and words). In this way, the curriculum content from which the students are going to learn in these last-mentioned subjects seems not to always be available for the students. Regarding the Swedish subject and its curriculum content, a classroom discourse emerges that takes somewhat for granted what suburban contexts can be or not, and what the students' experiences of their own living area are. 


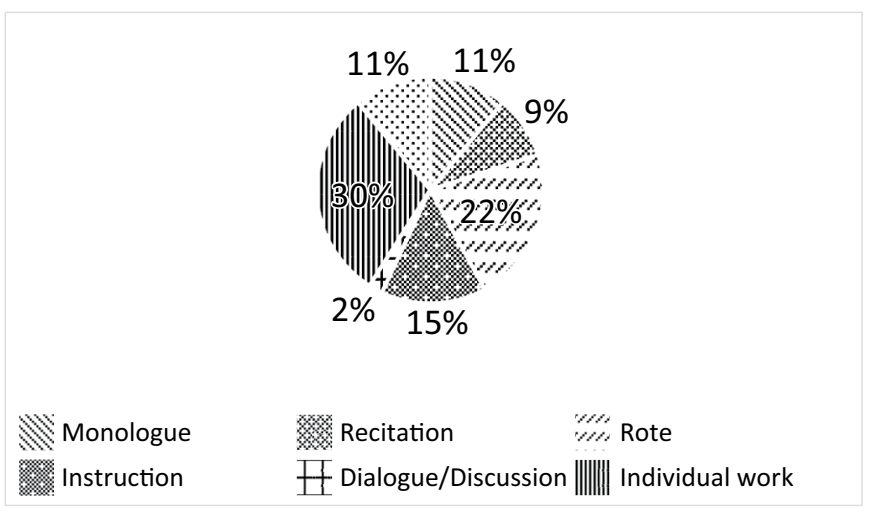

Figure 9.2 Organisation and teaching talk (\%)

\section{Teaching Factors}

The analysis of teaching factors, situated within the ten curriculum tasks, reveals that classroom practice is organised considerably through whole-class teaching $(70 \%)$ and individual work (30\%) (Figure 9.2). During whole-class teaching, the teacher functions or is supposed to function as the main actor using the following elements of teaching talk: rote $(22 \%)$, instruction $(15 \%)$, monologue (11\%), recitation (9\%) and dialogue/discussion (2\%). Students' individual work occurs after whole-class teaching. Although classroom practice is not organised through group/pair work, the students occasionally interact during individual work. Dialogue and/or discussion are hardly present. The lesson gaps category (11\%) affects some of the lessons.

\section{Students' Perspectives - Teaching Factors}

During whole-class teaching in Swedish, the teacher, according to the students and following the analysed teaching factors, usually goes through the lesson content and then instructs the students on how to proceed and on which individual work follows. Perjsa says, 'It is usually about texts; one has to read and write texts.' The student, Sara, expresses that she likes the lessons in Swedish and explains, 'I feel like I understand more and more.' Benny agrees with this and says, 'I actually feel the same thing.'

Some of the students are satisfied with the structure of teaching factors during the lessons in Swedish, while others find the tempo a bit tedious combined with too low expectations. Perjsa says, 'Well, the teacher could have explained this in a minute [referring to how to find counterargument in an argumentative text]; instead, the teacher extends and you stop listening.' Amale agrees with this and says, 'The teacher could have explained a bit faster.' Persja concludes, 'The teacher should just say, 'Take up your laptops and start writing.' In contrast to the last-mentioned students, Wahib finds the teacher's recitation during whole-class teaching to be a good thing: 


\section{Catarina Schmidt}

'Well, they explain until you get it.' In line with Wahib, the students, Boris and Josef, argue that a good teacher 'shall go through so that everyone would be carried along.'

During whole-class teaching in the Natural Sciences, the teacher, according to the students and following the analysed teaching factors, usually recites in front of the class what they should know, on which individual work follows. Regarding teaching in the Natural Sciences, Benny states, 'It is like the University, you sit and note what the teacher says and writes on the white board.' According to Jenica, it is 'hard to understand the teacher's explanations.' Benny and Mesude agree on this, and Mesude continues, 'You sit throughout the whole lesson and stare at the whiteboard, writing down words that you do not understand.' Also, Moukib and Wahib stress that the teacher cannot explain properly. The students, Perjsa, Diana, and Amale, collectively express that they find the lessons 'rather troublesome.' Benny suggests that 'it would be better to do experiments in front of the whole class' and continues, 'Then you can see with your eyes and understand better.' Benny's solution for the classroom situation is to sit and 'just take in as much as I can,' whereupon Jenica nods and agrees. In line with the other students, Boris and Josef also bring forward that they find it difficult to learn during the lessons in the Natural Sciences.

\section{Analytical Reflections - Teaching Factors}

Since whole-class teaching dominates classroom practices, to be followed by individual work, this means that the students are offered rather nondialogical classroom pedagogies with few possibilities of their own learning talk (Alexander, 2008). Also, this gives evidence that this group of students, where the majority are second-language learners, lack access to opportunities for exploration-based activities, including opportunities for active language use (Cummins, 2001; Schleppegrell, 2004; Schmidt \& Skoog, 2017, 2018). While some of the students find the tempo a bit tedious in Swedish subjects, combined with very low expectations, others are satisfied with the structure of teaching factors in this subject. This provides evidence that some of the students are not met with enough expectations. Regarding the subjects of the Natural Sciences, the students express in unified ways that they find it hard to learn during these lessons. The students seem, as I interpret their utterances, to be aware that the classroom pedagogies in these last-mentioned subjects do not function well and that they are withheld from far better alternatives regarding learning and developing knowledge in these subjects. The classroom discourse that emerges is characterised by narrowed repertoires of teaching factors, that is, organisation, teachers' teaching talk, and students' learning talk, with few opportunities for the students to actively participate, with very low expectations for many of them. 


\section{Classroom Actors}

The ways the teaching is organised, including the repertoires for interaction and communication, impact the student's opportunities regarding their participation and acting on an individual level and on their opportunities of interacting with other peers and the teacher. Since the classroom practice is organised through whole-class teaching $(70 \%)$ and individual work (30\%), this means that the students considerably listen, watch, or note when the teacher, through recitation, monologue and rote, is teaching. Also, the analysed teaching factors reveal that dialogues or discussions are seldom conducted, meaning that the teacher most often is the central actor of the classroom, while the students take on a more passive role. The analysed teaching factors reveal simultaneously that the category of lesson gaps (11\%) affects some of the lessons in Swedish and the Natural Sciences. This means that, quite often, there is a struggle as to who functions as the dominant actor in the classroom.

\section{Students' Perspectives - Classroom Actors}

Most of the students interpret student participation as being equal with being active during lessons. Jenica explains student participation in the following way, 'Well, the students actively participate, answer questions, and discuss, that is not sleeping or using the mobile phone.' All the students state that they take their responsibility of being attentive during lessons. Concurrently, many of them accentuate that it is difficult to always live up to this. Diana says, 'Well, it easily gets a little boring and repetitive, and then, you do not cope.' The repetitiveness occurs because, according to Jenica, 'some are on higher levels than others,' and she proposes that 'those students could be opportune to try on somewhat higher levels.' Mesude agrees, 'Yes, I feel restless to be at the same level always,' and Wahib adds, 'If you want to develop, you must get some more difficult stuffs.' All the students insist that they generally lack influence on the teaching and state that the teacher actually decides.

Most of the students criticise the teaching in the Natural Sciences. At the end of the school year, and with the summer holiday approaching, many students express anxiety regarding their learning in these subjects and their grades. Sara says, 'In the beginning of the semester, I was worried about my grades, but well, now I have lost my hope.' Sara explains further: 'We have discussed with one of our mentors and the principal, but no one does anything.' Jenicia, Sara, and Maria say that they want the classroom situation in the Natural Sciences to change. Sara says, 'If we were allowed to discuss, ask each other questions, and argue, then I think the information would stick much better.'

Also, most of the students panic regarding the recurring tests. Perjsa says, 'We have a test on Wednesday about heat, and as such, I am much afraid over that because I do not understand everything.' Perjsa develops her thoughts 


\section{6}

on this assessment, saying, 'this teacher just goes through things and then gives us a paper.' The students, Moukib, Wahib, Diana, and Amale, who have listened, nod their heads in agreement on this utterance. Sara observes, 'If I do not learn in grade eight, where will I turn in the upper secondary?' She continues, 'This is what I am disappointed at.'

Most of the students claim the classroom practices in both classrooms as 'messy,' in the sense that the teaching is interrupted, mainly due to disciplinary reasons. This condition greatly impacts the lessons and mostly during whole-class teaching. According to the students, there are certain students who disturb the classroom peace, but the situation affects, however, all the students. The students explain that because of this situation, they sometimes miss a great deal of the lesson, that it is harder to concentrate, and that one has to be one's own teacher. Concurrently, the students admit that they contribute to the disturbance in the classroom, like laughing, turning around, tapping on the phone, and so forth. Sara explains the classroom situation in the following way, 'We do not focus on one another, we are in the same classroom, but it is as if we are also on different places, it is as if someone is going on one train and another is watching Star Wars.'

\section{Analytical Reflections - Classroom Actors}

The student's perspectives show that they are aware of what student participation can be, and should be about, explained by one of them as actively participating, answering questions and discussing. Such student participation is, however, delimited due to the dominating teaching factors of whole-class and individual works, and also by the classroom disturbance, conducted by a few of the students. Therefore, the students cannot participate as central actors of the classroom, collaboratively with one another and with the teacher, with the consequence that the students cannot use language and texts actively and collaboratively, drawing on various curriculum content (Cummins, 2001; Schleppegrell, 2004; Schmidt \& Skoog, 2017, 2018). Furthermore, the student's perspectives elucidate what I describe as 'hopelessness' regarding the pedagogical situation in the subjects of Natural Sciences. Some of the students have tried to make their voices heard, aiming at changing the classroom situation, and several students have wisely and fruitfully suggested how to improve this classroom practice. The latter attempts are, however, not met, and hence unconsidered; instead, an option is left regarding being a central actor of the classroom (i.e. classroom disturbance). Regarding the student's opportunities of acting in the classroom, the classroom discourse is characterised by few opportunities for the students to engage with one another when learning and developing knowledge of subject-specific content in Swedish subjects and the Natural Sciences. In this way, the classroom discourse is also characterised by a distance towards the content that the students are going to learn about through active participation and interaction. 


\section{Concluding Thoughts}

The created classroom discourse comprises whole-class teaching, followed by individual work, mainly recitation or rote. The teaching in Swedish subject is characterised by dialogic recitation, aiming at meaning-making and developing abilities of reading comprehension and written communication. The teaching in the subject of Natural Sciences is characterised by the drilling of subject-specific concepts following an essentialistic approach of knowledge development, and conducted teaching in this direction. What we also see within this created classroom discourse is that these students are not encountering pedagogies that support them to develop sound relationships with one another. As Sara describes it, they are instead 'on different places concurrently; it is as if someone is going on one train and another is watching Star Wars.'

The student perspectives expressed in this chapter elucidate appreciation when exemplifying what they have learnt regarding various communicative abilities in Swedish subject. Concurrently, the student perspectives account that it would be possible to speed up the tempo to learn more and enhance the level of possible knowledge development. The student perspectives elucidate that they want more from the classroom pedagogies, which they are encountering. Simply put, they want to learn. Importantly, the student perspectives show an awareness of when they are learning or not and when the teaching they encounter is conducted in repetitious and non-dialogic ways, accompanied by low expectations and messy classroom situations.

Exploring Young's (2013) study, there is an urgent need to critically examine how different classroom discourses affect what counts as knowledge and to scrutinise how certain groups are excluded from accessing powerful knowledge. This narrative accounts for pedagogical segregation since most of these students within this school contexts are excluded from accessing knowledge, which they need in preparing for upper secondary school. Consequently, most of these students face circumstances that deny them of equal opportunities of both accessing upper secondary school and preparation for citizenship. The questions that arise from these conclusions are worrying: if these students are experiencing pedagogical segregation, what will it induce? If other students, just like these students, are also excluded instead of included in the current educational system, what will the consequences be? For individual students, this includes the risk of developing a low self-image, a feeling of not belonging, or being discounted as a legitimate citizen (Cummins, 2001; Runfors, 2003). For groups of students, living in multicultural areas with high socio-economic index, a sense of rightful disappointment risk to influence the whole groups of adolescents with a feeling of, again, not belonging and not counting as a legitimate citizen. For the individual student, for student groups within low-performing contexts, and for the society generally, this makes up for a dreadful failure. In the near future, and 
hence not in the long run, the conclusions just discussed risk altogether to threaten the very fundament of democracy. The obvious remark on this is that we can do better.

\section{Note}

1 The syllabus for the subject of Swedish as a second language is directed towards multilingual students, as a way to efficiently support their learning of Swedish. A student must study either Swedish or Swedish as a second language, and the time plan is equal.

\section{References}

Aldén, L., \& Hammarstedt, M. (2016). Boende med konsekvens - En ESO-rapport om etnisk bostadssegregation och arbetsmarknad. [Consequences of residential living An ESO-report about ethnical residential segregation and labour market]. Retrieved 10 June, 2021 from https://eso.expertgrupp.se/wp-content/uploads/2016/02/ Hela-2016_1-till-webben.pdf

Alexander, R. (2008). Essays on pedagogy. Routledge.

Antaki, C., \& Widdicombe, S. (1998). Identity as an achievement and as a tool. In C. Antaki, \& S. Widdicombe (Eds.), Identities in Talk (pp. 1-14). Sage Publications.

Berggren, M. (2016). Onsdag kväll strax före sju [Wednesday evening just before seven]. Opal Pocket.

Brandén, M., \& Bygren, M. (2018). School Choice and School Segregation: Lessons from Sweden's School Voucher System. The IAS Working Paper Series 2018 (1). Retrieved 10 June, 2021 from http://www.diva-portal.org/smash/get/diva2:1218847/ FULLTEXT02.pdf

Brinkmann, S. (2014). InterViews: Learning the craft of qualitative research. SAGE Publications.

Bunar, N. (2011). Multicultural urban schools in Sweden and their communities: Social predicaments, the power of stigma, and relational dilemmas. Urban Education, 46(2), 141-164.

Bunar, N., Hagström, M., \& Rojas, C. (2021). Barn och ungdomar $i$ stadens olikheter [Children and adolescens in the differences of the city]. Natur \& Kultur.

Cummins, J. (2001). Negotiating identities: Education for empowerment in a diverse society. California Association for Bilingual Education.

Cummins, J., \& Early, M. (Eds.). (2011). Identity texts: The collaborative creation of power in multilingual schools. Trentham Books.

Doyle, W. (1992). Curriculum and pedagogy. In P. W. Jackson (Ed.), Handbook of research on curriculum (pp. 486-516). Macmillan.

Foucault, M. (1993). Diskursens ordning. Brutus Östlings bokförlag.

Gibbons. (2008). 'It was taught good and I learned a lot': Intellectual practices and ESL learners in the middle years. Australian Journal of Language and Literacy, $31(2), 155-173$.

Government Offices. (2017). Stärkt digital kompetens [Reinforced digital competence]. Retrieved 13 June, 2021 from https://www.regeringen.se/pressmeddelanden/2017/03/starkt-digital-kompetens-i-laroplaner-och-kursplaner/

Hammersley, M., \& Atkinson, P. (1989). Ethnography. Principles in practice. Routledge. 
Hsieh, H-F., \& Shannon, S. E. (2005). Three approaches to qualitative content analysis. Qualitative Health Research, 15(9), 1277-1288.

Johansson, T., \& Hammarén, N. (2011). The art of choosing the right tram: Schooling, segregation and youth culture. Acta Sociologica, 54(1), 45-59.

National Agency of Education. (2012). Likvärdig utbildning $i$ svensk grundskola? [Equal education in Swedish compulsory education?]. Retrieved 10 June, 2021 from https://www.skolverket.se/publikationsserier/rapporter/2012/likvardig-utbildning-i-svensk-grundskola-en-kvantitativ-analys-av-likvardighet-overtid.?id=2816

National Agency of Education. (2018). Analyser av familjebakgrundens betydelse för skolresultaten och skillnader mellan skolor. En kvantitativ studie av utvecklingen över tid $i$ slutet av grundskolan [Analysis of the impact of family background on school results and differences between schools. A quantiatative study of the development over time in the end of the compulsory school years]. Retrieved 30 March, 2020 from https: / / www.skolverket.se / getFile?file $=3927$

National Agency of Education. (2019a). PISA 2018. 15-åringars kunskaper $i$ läsförståelse, matematik och naturvetenskap [PISA 2018. 15-year olds knowledges in reading comprehension, mathematics and natural sciences]. Retrieved 30 March, 2020 from https://www.skolverket.se /getFile?file $=5347$

National Agency of Education. (2019b). Statistics. Retrieved 30 March, 2020 from https://www.skolverket.se/skolutveckling/statistik/sok-statistik-om-forskola-skola-och-vuxenutbildning? sok=SokC\&omrade $=$ Skolor $\% 20$ och $\% 20$ elever\&lasar $=2019 / 20 \&$ run $=1$

National Agency of Education. (2020). Skolverkets lägesbedömning [National Agency of Education: Situation Assessment]. Retrieved 11 June, 2021 from https://www.skolverket.se/publikationsserier/rapporter/2020/skolverketslagesbedomning-2020

Runfors, A. (2003). Mångfald, motsägelser och marginaliseringar: en studie av hur invandrarskap formas $i$ skolan [Diversity, contradictions and marginalisations: a study of how migrationship is shaped in school]. Prisma.

Schleppegrell, M. (2004). The language of schooling: A functional linguistics perspective. Lawrence Erlbaum Associates.

Schmidt, C. (2019). Classroom observations through video recordings Methodological approaches and ethical considerations. In N. Wahlström (Ed.), Classroom research: Methodology, categories and coding (pp. 16-21). Linneaus University Press.

Schmidt, C., \& Skoog, M. (2017). Classroom interaction and its potential for literacy learning. Nordic Journal of Literacy Research, 13, 45-60.

Schmidt, C., \& Skoog, M. (2018). The question of teaching talk: Targeting diversity and participation. In N. Wahlström, \& D. Sundberg (Eds.), Transnational curriculum standards and classroom practices. The new meaning of teaching (pp. 83-97). Routledge.

SFS. 2010:800. The Education Act. Stockholm: Utbildningsdepartementet.

SOU. 2020:46. En gemensam angelägenhet [A shared concern]. Retrieved $30 \mathrm{March}$, 2020 from https://www.regeringen.se/rattsliga-dokument/statens-offentligautredningar/2020/08/sou-202046/

Wahlström, N. (2018). When transnational curriculum policy reaches classrooms teaching as directed exploration. Journal of Curriculum Studies, 50(5), 654-668. doi:10.1080/00220272.2018.1502811 


\section{Catarina Schmidt}

Wahlström, N. (Ed.). (2019). Classroom research: Methodology, categories and coding. Linneaus University Press.

Wedin, Å. (2015). Non-challenging education and tealcher control as factors for marginalization of students in diverse settings. International Electronic Journal of Elementary Education, 7(2), 169-188.

Xerri, D. (2018). The use of interviews and focus groups in teacher research. The Clearing House: A Journal of Educational Strategies, Issues and Ideas, 91, 140-146.

Young, M. F. D. (2013). Overcoming the crisis in curriculum theory: A knowledge-based approach. Journal of Curriculum Studies, 45(2), 101-118.

Zubak, I. (2017). Måste gitt [Have to walk away] [Film]. Film i Väst; Indian Summer Film. 